\title{
Effect of Pre-Harvest Application of Hydrogen Cyanamide and Abscisic Acid (ABA) on Time of Ripening and Fruit Quality of Flame Seedless Grape (Vitis vinifera L.)
}

\author{
Ashok Kumar Mahawer", N.K. Arora and M.I.S. Gill \\ Department of Fruit Science, Punjab Agricultural University Ludhiana - 141004 (Punjab), India \\ *Corresponding author
}

A B S T R A C T

Keywords

Abscisic acid (ABA), Ethephon,

Flame Seedless,

Fruit quality, HCNs, Time of ripening.

Article Info

Accepted:

07 September 2017

Available Online:

10 October 2017
An experiment was conducted to ascertain the effect hydrogen cyanamide (HCN) @ 2 per cent $a . i$ and abscisic acid (ABA) on time of ripening and fruit quality of Flame Seedless grapes. The treatment $\left(\mathrm{T}_{6}-\mathrm{HCN} @ 2 \%+\mathrm{ABA} @ 100 \mathrm{ppm}\right)$ had advanced the time of ripening by 9 -days as compared to untreated (control). Likewise, the maximum bunch weight $(384.67 \mathrm{~g})$ was recorded in a treatment in which 2 per cent $\mathrm{HCN}+100 \mathrm{ppm}$ of ABA was applied at veraison stage. Grapevines treated with 2 per cent $\mathrm{HCN}+100 \mathrm{ppm}$ $\mathrm{ABA}+400 \mathrm{ppm}$ ethephon had lowest uneven colour of berries/bunch $(16.78 \%)$. The maximum TSS was also recorded in $\mathrm{T}_{3}(\mathrm{HCN} 2 \%+100$ ppm ABA), while lowest acidity was recorded in treatment $\mathrm{T}_{6}(\mathrm{HCN} 2 \%+100 \mathrm{ppm} \mathrm{ABA}+400 \mathrm{ppm}$ ethephon). The maximum $(41.87 \mathrm{mg} / 100 \mathrm{~g})$ anthocyanin content was recorded in treatment $\mathrm{T}_{3}$ i.e. $\mathrm{HCN}$ (2 $\%)+100 \mathrm{ppm}$ ABA. The present study suggested that pre-harvest treatment of 2 per cent $\mathrm{HCN}$ (at end of December) + $100 \mathrm{ppm} \mathrm{ABA} \mathrm{(at} \mathrm{veraison} \mathrm{stage)} \mathrm{was} \mathrm{helpful} \mathrm{in} \mathrm{advancement}$ of ripening and improvement in fruit quality in Flame Seedless grapes.

\section{Introduction}

India has 3.31 per cent share of world grapes production. At present, grapes occupies an area of 122 thousands ha with an annual production 2590 thousand MT (Anonymous 2015-16). Maharashtra is a largest producer of the grapes in the country and contributed 75 per cent of the total domestic production. The cultivars like Thomson Seedless, its clones Tas-e-Ganesh, Manik-Chaman and Sharad Seedless are the major commercial cultivars of this region. In north-western Indian plains the grape cultivation is confined to Punjab, Haryana, parts of Rajasthan and Uttar Pradesh. In this region 'Parlette' variety of grapes has been widely cultivated and it's occupied about 90 per cent area under grapes. To restrict the monoculture of 'Perlette' in northern states of India, The Punjab Agricultural University, Ludhiana has recommended coloured grape variety 'Flame Seedless' for commercial cultivation in the state. Flame Seedless developed by $\mathrm{J}$. Weinberger and F. Harmon in 1989 (Van der Merwe et al., 1991). This variety has an edge over commercial grape variety Perlette as it has crimson red colour, seedless berries, relatively higher yield, better TSS: acid ratio and bunch is medium and well filled and long shelf life. It ripens a week later than Perlette and reduce market glut due to Perlette. 
Although 'Flame Seedless' cultivar of grapes has many advantages over 'Perlette' However, in sub-tropical conditions it exhibits a problem of uneven colour development because high temperature inhibits anthocyanin accumulation in grape berry skin (Spayed et al., 2002; Yamane and Shibayama 2006). Further under subtropical conditions, this variety ripen during $2^{\text {nd }}$ week of June, often this time coincide with premonsoon rainfall, which may cause the fear among grape growers. Hence, there is an urgent need to advancement in time of ripening of Flame Seedless grapes, so it can escape from damage of pre-monsoon rainfall. Previously, various attempts have been made to promote early bud burst and ripening by using hydrogen Cyanamide immediately after pruning (Pandey, 1989; Arora et al., 2011). In recent past, efforts have also been made by various worker's to improve the colour of this variety with bunch thinning and foliar application of ethephon (and Kaur et al., 2013). However, the uniform ripening of the berries has not been achieved successfully. Therefore, in the present studies an attempt has been be made to advance the time of ripening and improvement in the fruit quality of Flame Seedless grapes by attaining uniform colour with the cumulative application of hydrogen cyanamide and abscisic acid (ABA).

\section{Materials and Methods}

The experiment were conducted on 14-yearsold own rooted grape vines of $c v$. 'Flame Seedless' grapes trained on bower's system and planted at $3 \mathrm{~m} \times 3 \mathrm{~m}$ distance at the Fruit Research Farm, Department of Fruit Science, Punjab Agricultural University, Ludhiana, during 2015 fruiting season received uniform cultural practices during the studies period. The various treatment consists of $\mathrm{T}_{1}$ (Hydrogen Cyanamide 2\% + 50 ppm ABA); $\mathrm{T}_{2}$ (Hydrogen Cyanamide 2\% + $75 \mathrm{ppm}$ ABA); $\mathrm{T}_{3}$ (Hydrogen Cyanamide $2 \%+100$ ppm ABA); $\mathrm{T}_{4}$ (Hydrogen Cyanamide $2 \%+$ $50 \mathrm{ppm}$ ABA $+400 \mathrm{ppm}$ Ethephon); $\mathrm{T}_{5}$ (Hydrogen Cyanamide 2\% + 75 ppm ABA + 400 ppm Ethephon); $\mathrm{T}_{6}$ (Hydrogen Cyanamide $2 \%+100 \mathrm{ppm} \mathrm{ABA}+400 \mathrm{ppm}$ Ethephon); $\mathrm{T}_{7}$ (Hydrogen Cyanamide $2 \%+$ 400 ppm Ethephon); $T_{8}$ (75\% crop load +400 ppm Ethephon (Local recommended practice) and $\mathrm{T}_{9}$ Control (untreated).

The Flame Seedless vines were pruned to 4 buds level during end December (except vines of treatments $\mathrm{T}_{8}$ and $\mathrm{T}_{9}$ ). The hydrogen cyanamide@ 2 per cent active ingredient was sprayed on canes of pruned vines immediately after pruning. In case of treatments $\mathrm{T}_{8}$ (recommended technology) and $\mathrm{T}_{9}$ (control), vines were pruned to four buds level during last week of January i.e. recommended time of pruning in grapes under northern Indian conditions. Barring control $\left(\mathrm{T}_{9}\right)$, in all the treatments 75-80 bunches were retained at time of bunches emergences. The various concentration of $\mathrm{ABA}$ and ethephon was sprayed under different treatments at colour break stage. At time of spray tween-20 @ $1 \mathrm{ml} /$ liter were also added for increasing the effectiveness of growth regulators. At time of ripening, fruit were harvested from all the replication during morning hours \& immediately transfer to viticulture laboratory of Department of Fruit Science, PAU, Ludhiana for analysis of fruits by employing standard procedures (AOAC, 1990). The data recorded were analyzed for variance by using SAS (V 9.3, SAS Institute Inc., USA). The treatment means are subjected to mean separation by Least Significant Difference (LSD, $\mathrm{p} \leq 0.05$ ).

\section{Results and Discussion}

\section{Time of ripening}

The data revealed that earliest fruit ripening was observed on $1^{\text {st }}$ June, (advanced time of ripening by 9 -days as compared to control) in 
the treatment $T_{3}$ in which vines were treated with HCN 2 per cent at end of December and 100 ppm ABA at veraison stage (Fig. 1). This was followed by treatments $\mathrm{T}_{1}(\mathrm{HCN} 2 \%+$ ABA $50 \mathrm{ppm})$ and $\mathrm{T}_{2}(\mathrm{HCN} 2 \%+\mathrm{ABA} 75$ ppm) resulted in advancement in ripening by 8 days as compared to control. Whereas, the treatment $\mathrm{T}_{5}(\mathrm{HCN} 2 \%+75 \mathrm{ppm} \mathrm{ABA}+400$ ppm ethephon) fruits was ripened 5-days advance as compared to control.

The treatment $\mathrm{T}_{8}(75 \%$ crop load $+400 \mathrm{ppm}$ ethephon application) was led to advancement in ripening by two days only as compared to control. In present studies, the advancement of ripening was due to treatment of vines with $\mathrm{HCN}$ which is a chemical help in advancement of time of ripening and early bud burst by breaking the dormancy. In treated vines, the treatment with ripening hormone ABA/ Ethephon also caused the synergist effect along with $\mathrm{HCN}$ in advancement in ripening as compared to control/ untreated vines. Previously, Pandey, 1989 in Pusa Seedless grapes and Arora et al., (2011) in 'Perlette' grapes observed advancement in time of ripening in vines treated with $\mathrm{HCN}$ immediately after pruning. Likewise, Singla et al., (1992) found that ethephon at $750 \mathrm{ppm}$ advanced the time of ripening by 7-days in 'Early Muscat' and by 8 -days in $c v$. Gold. Similarly, abscisic acid has traditionally been considered as the main triggering signal for the onset of ripening in grapes berries, grapevine showed an increase in $\mathrm{ABA}$ concentration in berries just before veraison stage. ABA concentration is very low in unripe fruit, but it increases as a fruit ripens, so it is therefore, considered that $\mathrm{ABA}$ plays an important role in regulating the rate of fruit ripening (Setha 2012).

\section{Yield (kg/vine) and marketable yield}

The pre-harvest application of $\mathrm{HCN}, \mathrm{ABA}$ and ethephon significantly affected the fruit yield in Flame Seedless grapes (Table 1). The treatment $\mathrm{T}_{3}$ i.e. ( $\mathrm{HCN} 2 \%+100$ ppm ABA) was recorded highest fruit yield and it was significantly higher yield (32.94 kg/vine) as compared to other treatment. In control the higher fruit yield was recorded due to grapevines were retained with 100 per cent crop load (110-120 bunches/vine).

The treatments $\mathrm{T}_{2}(\mathrm{HCN} @ 2 \%+\mathrm{ABA} @ 75$ ppm) and $\mathrm{T}_{8}$ (75\% crop load +400 ppm ethephon) recorded $28.27 \mathrm{~kg}$ and $27.31 \mathrm{~kg}$ fruit yield per vine, respectively, which was significantly lower than fruit yield (30.75 $\mathrm{kg} / \mathrm{vine}$ ) recorded in control.

Leao and Silva (2004) studied the effect of hydrogen cyanamide on 'Italia' table grape cultivar, in the Sao Francisco River Valley and found that increments of 68 per cent and 84 percent in the yield per plant, respectively in the $1^{\text {st }}$ and $2^{\text {nd }}$ harvest seasons. Quiroga et al., (2009) found that the application ABA on vines of grape $c v$. 'Cabernet Sauvignon', it likely to be enhance bunch per plant by (1.1to 1.3 -fold) across all three harvests.

The highest marketable yield (27.02 kg/vine) was recorded with application of treatment $\mathrm{T}_{3}$ i.e. (HCN $2 \%+100$ ppm ABA) which was significantly higher than other treatments (Table 1). This was followed by the treatments $\mathrm{T}_{6}(\mathrm{HCN} 2 \%+\mathrm{ABA}+100 \mathrm{ppm}$ $\mathrm{ABA}+400 \mathrm{ppm}$ ethephon) recorded $25.2 \mathrm{~kg}$ marketable yield per vine (Fig. 3).

The lowest marketable yield per vine was recorded with $\mathrm{T}_{9}$ (control). In present studies, higher marketable yield in vines treated with ABA and ethephon attributed to higher number of uniform bunches in these treatments as compared to control. Likewise, previously Mehta and Chundawat (1979) and Dokoozlian et al., (1995) reported uniform colour development in berries with application of ethephon. 
Table.1 Effect of pre-harvest application of hydrogen cyanamide, ABA and ethephon on yield, marketable yield and bunch weight of flame seedless grapes

\begin{tabular}{|c|l|c|c|c|}
\hline \multicolumn{2}{|c|}{ Treatments } & $\begin{array}{c}\text { Yield } \\
\text { (kg/vine) }\end{array}$ & $\begin{array}{c}\text { Marketable } \\
\text { Yield } \\
\text { (kg/vine) }\end{array}$ & $\begin{array}{c}\text { Bunch } \\
\text { weight (g) }\end{array}$ \\
\hline $\mathrm{T}_{1}$ & HCN 2\% + 50 ppm ABA & 30.06 & 22.18 & 343.60 \\
\hline $\mathrm{T}_{2}$ & HCN 2\% + 75 ppm ABA & 28.27 & 22.79 & 351.73 \\
\hline $\mathrm{T}_{3}$ & HCN 2\% + 100 ppm ABA & 32.94 & 27.02 & 384.67 \\
\hline $\mathrm{T}_{4}$ & HCN 2\% + 50 ppm ABA + 400 ppm Ethephon & 29.20 & 23.67 & 368.90 \\
\hline $\mathrm{T}_{5}$ & HCN 2\% + 75 ppm ABA + 400 ppm Ethephon & 29.58 & 23.11 & 367.27 \\
\hline $\mathrm{T}_{6}$ & HCN 2\% + 100 ppm ABA + 400 ppm Ethephon & 30.28 & 25.20 & 371.99 \\
\hline $\mathrm{T}_{7}$ & HCN 2\% + 400 ppm Ethephon & 28.76 & 23.43 & 362.80 \\
\hline $\mathrm{T}_{8}$ & 75\% C.L + 400 ppm Ethephon (Recommended) & 27.31 & 20.60 & 351.40 \\
\hline $\mathrm{T}_{9}$ & Control (untreated) & 30.75 & 17.67 & 283.47 \\
\hline & LSD (p $\leq \mathbf{0 . 0 5})$ & $\mathbf{2 . 0 6}$ & $\mathbf{1 . 6 8}$ & $\mathbf{2 8 . 9 2}$ \\
\hline
\end{tabular}

Table.2 Effect of pre-harvest application of hydrogen cyanamide, ABA and ethephon application on total soluble solids and acidity of flame seedless grapes

\begin{tabular}{|l|l|c|c|}
\hline \multicolumn{1}{|c|}{ Treatments } & TSS (\%) & Acidity (\%) \\
\hline $\mathrm{T}_{1}$ & HCN 2\% + 50 ppm ABA & 17.40 & 0.51 \\
\hline $\mathrm{T}_{2}$ & HCN 2\% + 75 ppm ABA & 16.30 & 0.50 \\
\hline $\mathrm{T}_{3}$ & HCN 2\% + 100 ppm ABA & 18.43 & 0.48 \\
\hline $\mathrm{T}_{4}$ & HCN 2\% + 50 ppm ABA + 400 ppm Ethephon & 16.60 & 0.58 \\
\hline $\mathrm{T}_{5}$ & HCN 2\% + 75 ppm ABA + 400 ppm Ethephon & 16.90 & 0.52 \\
\hline $\mathrm{T}_{6}$ & HCN 2\% + 100 ppm ABA + 400 ppm Ethephon & 16.97 & 0.46 \\
\hline $\mathrm{T}_{7}$ & HCN 2\% + 400 ppm Ethephon & 16.77 & 0.52 \\
\hline $\mathrm{T}_{8}$ & 75\% C.P + 400 ppm Ethephon (Recommended) & 17.17 & 0.56 \\
\hline $\mathrm{T}_{9}$ & Control (untreated) & 15.93 & 0.61 \\
\hline & LSD (p $\leq \mathbf{0 . 0 5})$ & $\mathbf{0 . 8 6}$ & $\mathbf{0 . 1 3}$ \\
\hline
\end{tabular}

Table.3 Effect of pre-harvest application of hydrogen cyanamide, ABA and ethephon application on anthocyanin content $(\mathrm{mg} / 100 \mathrm{~g})$ and uneven colour of berries/bunch (\%) of flame seedless grapes

\begin{tabular}{|c|l|c|c|}
\hline $\begin{array}{c}\text { S. } \\
\text { No. }\end{array}$ & \multicolumn{1}{|c|}{ Treatments } & $\begin{array}{c}\text { Uneven colour of } \\
\text { berries/bunch (\%) }\end{array}$ & $\begin{array}{c}\text { Anthocyanin } \\
\text { content (mg/100 g) }\end{array}$ \\
\hline $\mathrm{T}_{1}$ & HCN 2\% + 50 ppm ABA & 26.22 & 29.87 \\
\hline $\mathrm{T}_{2}$ & HCN 2\% + 75 ppm ABA & 19.41 & 37.83 \\
\hline $\mathrm{T}_{3}$ & HCN 2\% + 100 ppm ABA & 17.97 & 41.87 \\
\hline $\mathrm{T}_{4}$ & HCN 2\% + 50 ppm ABA + 400 ppm Ethephon & 18.93 & 34.39 \\
\hline $\mathrm{T}_{5}$ & HCN 2\% + 75 ppm ABA + 400 ppm Ethephon & 21.86 & 39.20 \\
\hline $\mathrm{T}_{6}$ & HCN 2\% + 100 ppm ABA + 400 ppm Ethephon & 16.78 & 40.16 \\
\hline $\mathrm{T}_{7}$ & HCN 2\% + 400 ppm Ethephon & 18.54 & 34.80 \\
\hline $\mathrm{T}_{8}$ & 75\% C.P + 400 ppm Ethephon (Recommended) & 24.59 & 29.60 \\
\hline $\mathrm{T}_{9}$ & Control (untreated) & 42.52 & 26.37 \\
\hline & LSD (p $\leq \mathbf{0 . 0 5 )}$ & $\mathbf{1 . 8 7}$ & $\mathbf{1 . 0 4}$ \\
\hline
\end{tabular}


Fig.1 Effect of pre-harvest application of hydrogen cyanamide, ABA and ethephon on time of ripening of flame seedless grapes

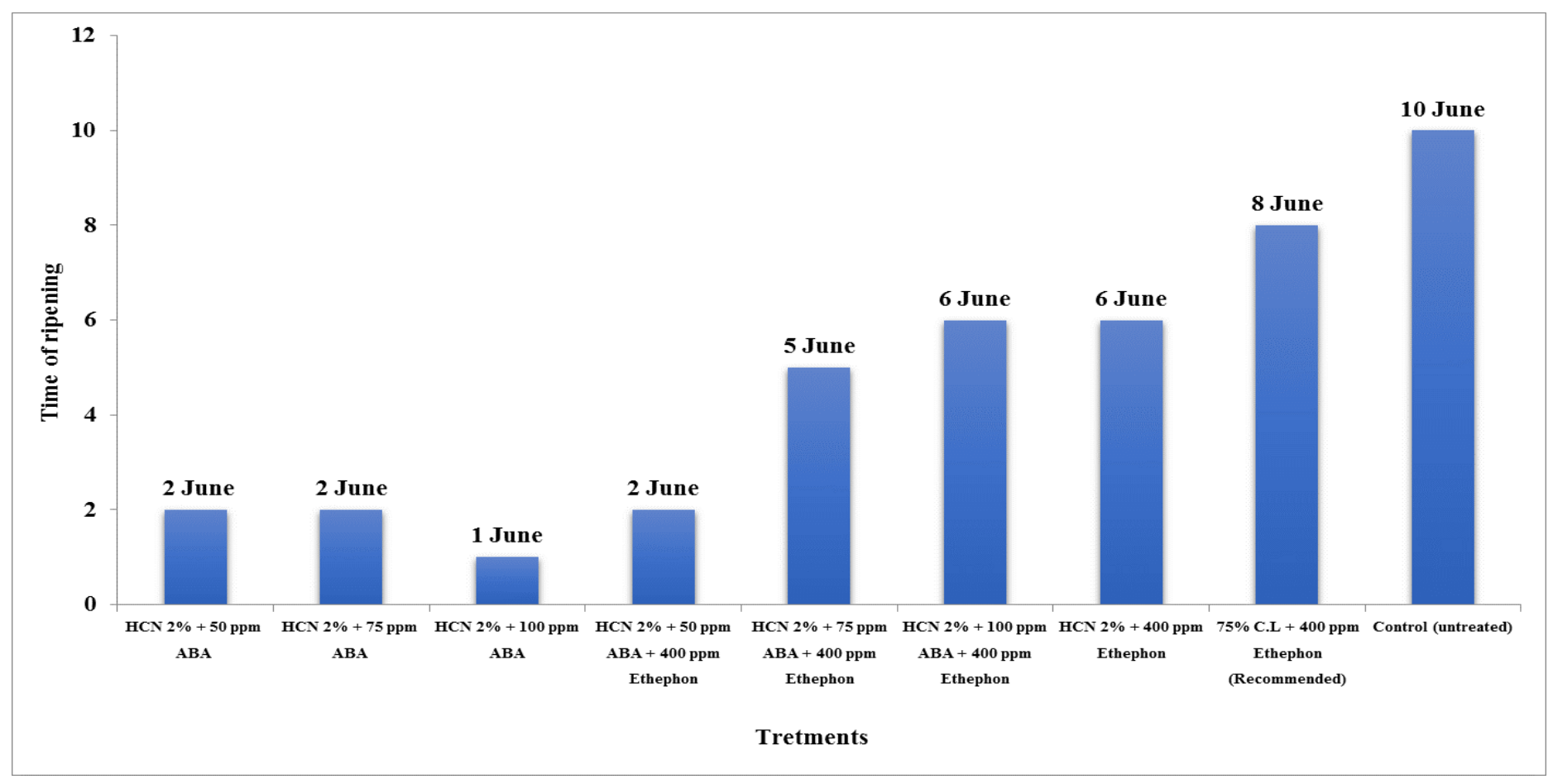

Fig.2 Effect of pre-harvest application of hydrogen cyanamide, ABA and ethephon on anthocyanin and uneven colour of barriers/bunches of flame seedless grapes

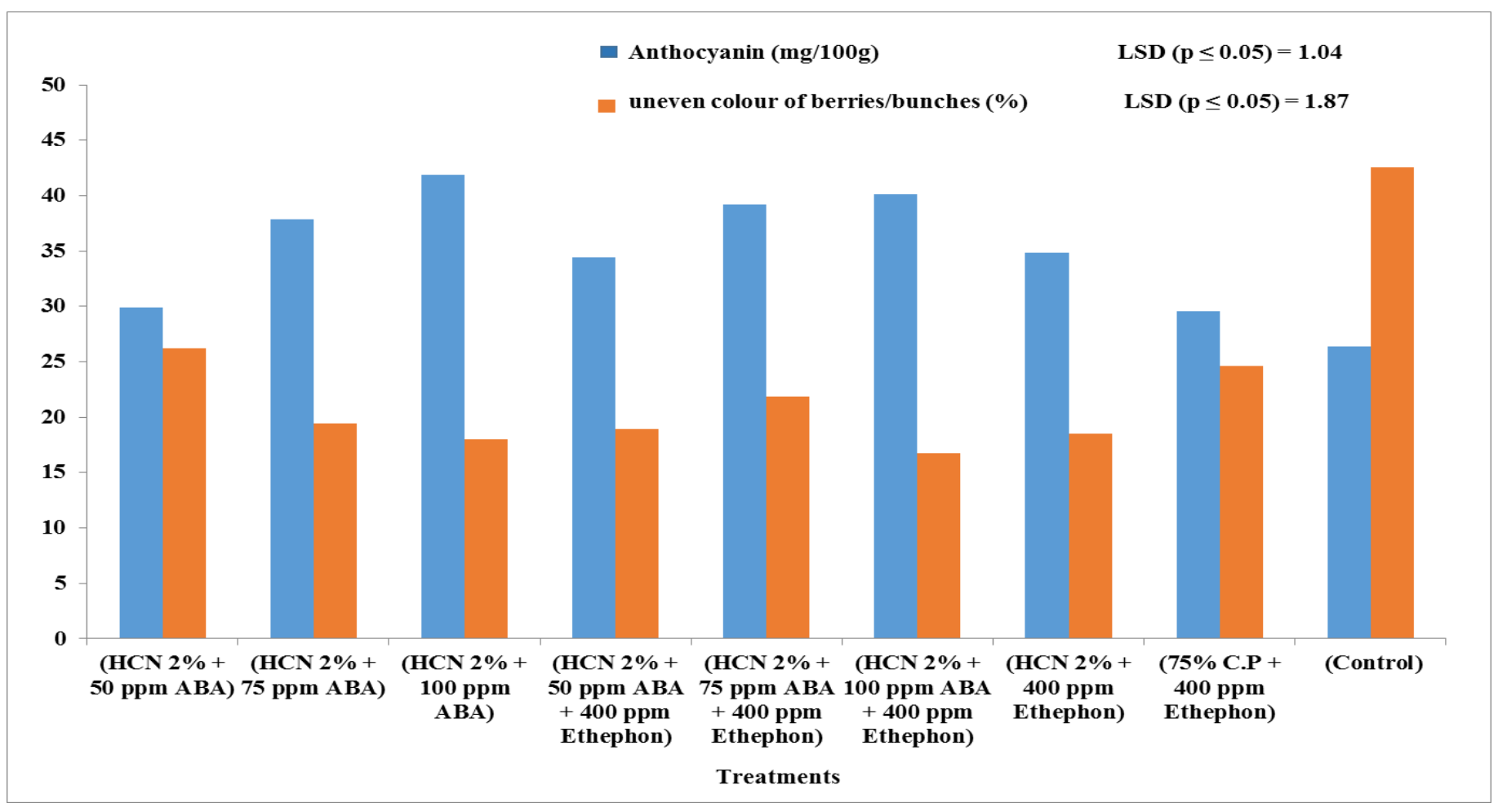


Fig.3 Effect of pre-harvest application of hydrogen cyanamide, ABA and ethephon on yield and marketable yield of flame seedless grapes

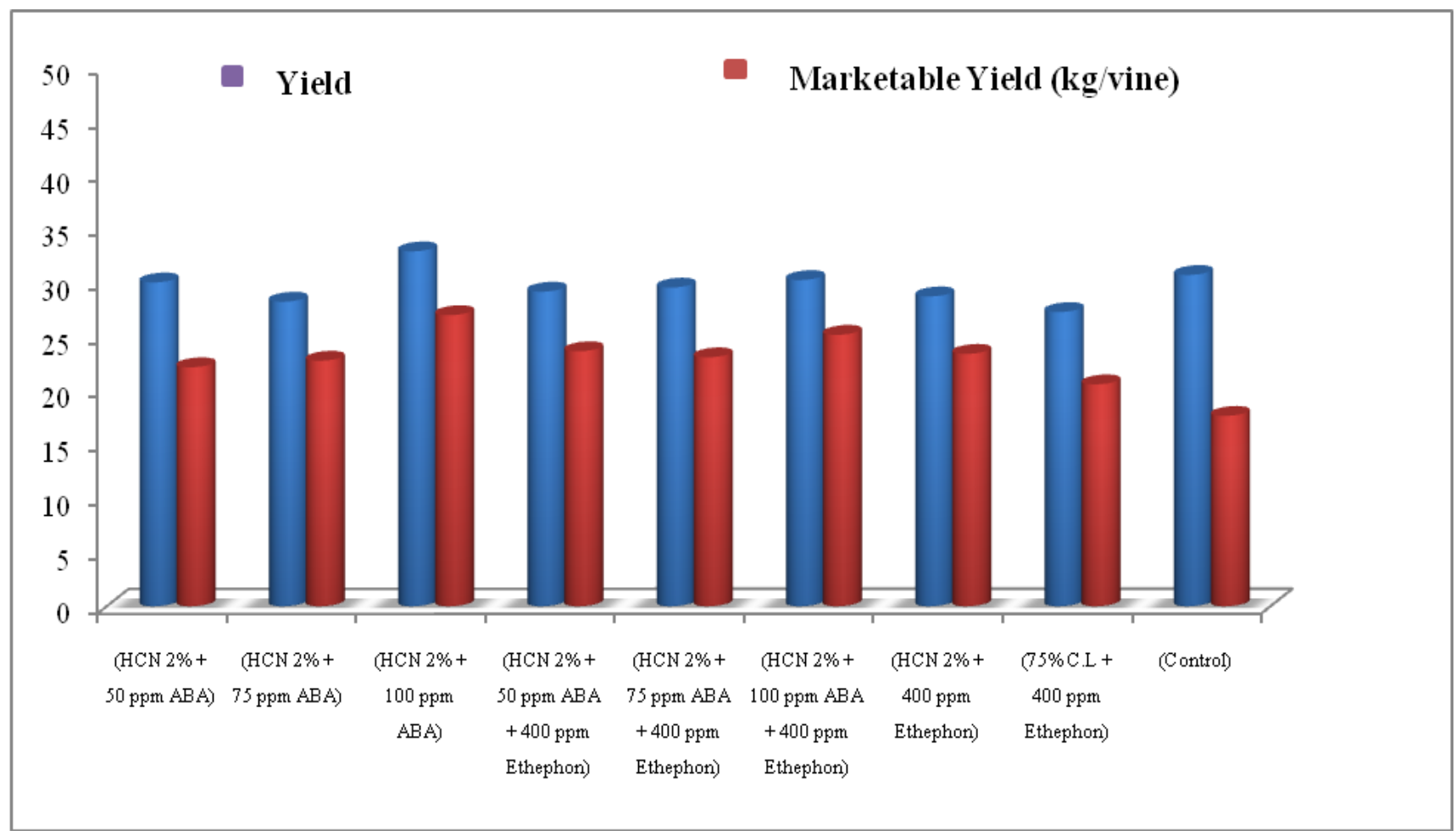

\section{Bunch weight (g)}

The vines treated with $\mathrm{HCN} 2$ per cent and 100 ppm ABA $\left(\mathrm{T}_{3}\right)$ was resulted in a higher bunch weight (384.67 g) as compared to untreated vines $(283.47 \mathrm{~g})$ which was statistically at par with $\mathrm{T}_{4}, \mathrm{~T}_{5}$ and $\mathrm{T}_{7}$ (Table 1). In case of untreated vines (100\% crop load) minimum bunch weight $(283.47 \mathrm{~g})$ was recorded. Previously, Kaur et al., (2013) showed that the application of ethephon @ $500 \mathrm{ppm}$ alone or in combination with 50 per cent crop load leads to highest bunch weight in grape $c v$. Flame Seedless grapes. Similarly, Hyun et al., (1996) also found the higher bunch weight was recorded with ethephon treatments applied at veraison in 'Kyoho' grapes. Muhtaseb and Ghnaim (2008) studied the effect of time of application of Dormex®. They found that Dormax treated vines had significantly higher fruit weight.
Total soluble solids (\%) and acidity (\%) contents of fruit

The highest mean TSS (18.43\%) was recorded with treatment $\mathrm{T}_{3}$ i.e. $\mathrm{HCN} 2$ percent +100 ppm of ABA (Table 2). In case of untreated vines (control), the least percentage of total soluble solids 15.93 per cent was recorded. This was statistically at par with treatments $\mathrm{T}_{2}$, $\mathrm{T}_{4}$ and $\mathrm{T}_{7}$ in which $16.3,16.6,16.77$ total soluble solids with T9 (15.93) was recorded. The present study revealed that higher TSS was noted in fruits harvested from grapevines maintained with HCN 2 percent, 100 ppm application of ABA. These results are in conformity with the findings of Amiri et al., (2009) and Arora et al., (2011).

The treatment $\mathrm{T}_{6}$ i.e. $(\mathrm{HCN} 2 \%+\mathrm{ABA} 100$ ppm +400 ppm ethephon) was recorded lowest mean acidity $(0.46 \%)$ which was statistically at par with $\mathrm{T}_{3}$ i.e. (HCN $2 \%+100$ 
ABA) (Table 2). The control (100\% crop load) had highest $(0.60 \%)$ mean acidity. The vines under control recorded the highest $(0.61$ $\%)$ fruit acidity per cent which was significantly more than superior treatment $\left(\mathrm{T}_{6}\right)$. The results are in conformity with finding of Collalto et al., (1991), Amati et al., (1994) and Gaser et al., (1998). On same line, Peppi et al., (2006) reported that treatment with ABA reduced titratable acidity in 'Flame Seedless' grapes.

\section{Anthocyanin content (mg/100 g)}

All the treatments resulted in increase in anthocyanin content as compared to control (Fig. 2). The maximum (41.87 $\mathrm{mg} / 100 \mathrm{~g})$ anthocyanin content was recorded in treatment $\mathrm{T}_{3}$ (HCN 2\% + $100 \mathrm{ppm}$ ABA) which was statistically at par with the treatment $\mathrm{T}_{6}$ i.e. $(\mathrm{HCN} 2 \%+100$ ppm ABA +400 ppm ethephon) recorded $40.16 \mathrm{mg}$ anthocyanin per $100 \mathrm{gm}$ of pulp. The results of present investigations showed that with increase in ABA (100) and ethephon (400 ppm) concentration, anthocyanin content was increased. Similarly, the application of ethephon on grapes during veraison stage results in the highest contents of total anthocyanin which translates into higher visual colour intensities of grapes (Lombard et al., 2004). Amiri et al., (2009) reported that application of ABA was more effective than ethephon for enhancing the colour and total anthocyanin content. Quiroga et al., (2009) observed higher level of anthocyanin relative to control values with $\mathrm{ABA}$ application in field-grown grape $c v$. 'Cabernet Sauvignon'.

\section{Uneven colour of berries/bunch (\%)}

The significant improvement was observed in uniform coloured berries per bunch under different treatments as compared to control (Fig. 2). The significantly lowest uneven berries per bunch (16.78\%) are recorded in treatment $\mathrm{T}_{6}(\mathrm{HCN} 2 \%+100$ ppm of $\mathrm{ABA}+$ $400 \mathrm{ppm}$ ethephon). This was statistically at par with treatments $T_{3}$ and $T_{7}$ in which 17.97 and 18.54 per cent of uneven berries per bunch were recorded, respectively. The highest 42.52 $\%$ uneven berries per bunches was recorded in untreated (control) grapevine (Table 3). Mehta and Chundawat (1979) reported that uniform colour development was observed with 500 ppm ethephon at veraison stage in 'Beauty Seedless' and 'Pinot Noir' grapes. Panwar et al., (1994) also reported that ethephon sprayed at veraison reduced the number of unevenly ripened berries in Beauty Seedless grapes.

\section{References}

Amati, A., Marangoni B, Zironi R, Graziani N, Castellari M and Arfelli G. 1994. The effect of cluster thinning on vine growth and yield parameters. Rivista-e-di-Enologia. 47: 13-27.

Amiri, M.E., Fallahi E and Parseh S. 2009. Application of ethephon and ABA at $40 \%$ veraison advanced maturity and quality of 'Beidaneh Ghermez' grape. Acta Hort. 884: 371-77.

Anonymous, 2015-16. Indian Horticulture Data Base. National Horticulture Board, Ministry of Agriculture Government of India. www.nhb.gov.in.

AOAC, 1990. Official Methods of Analysis, $14^{\text {th }}$ Edition. Association of Official Analytical Chemists, Washington D.C. USA.

Arora, N.K., Gill M I S, Navjot. 2011. Effect of hydrogen cyanamide on enhancing bud burst, maturity and improving fruit quality of Perlette grapes. Indian J. Plant Physiol. 16:218-21.

Arora, N.K., Singh I, Gill M I S, Alam M S and Navjot. 2012. Effect of time of ethephon application on ripening, colour development and storage life of Flame Seedless grapes in subtropical conditions. Fifth Indian Horticulture Congress. pp 446- 47.

Collatto, G., Di, Ferrinie F and Biricolti S. 1991. Results of research on grapes cluster thinning in the Tuscan hills. Vignevini. 18: 7-8.

Dokoozlian, N., Luvisi D, Moriyana $\mathrm{M}$ and Schrader P. 1995. Cultural practices improve 
colour, size of Crimson Seedless. Calif Agric. 49: 36-39.

Gaser, A.S.A., Ibrahim F E and Wally A S M. 1998. Effect of preharvest applications of gibberellic acid, hand thinning and ethrel on bunch characteristics, quality of 'Flame Seedless' grape and storability. Ann Agric Sci. 36: 1701-2.

Hyun, D.H., Lee S M, Lee C H and Kim S B. 1996. Effect of ABA and ethephon treatments on colouration and fruit quality of Kyoho grape. J Korean Soc Hort Sci. 37: 416-20.

Kaur, M., Gill M I S and Arora N K. 2013. Effect of pre-harvest treatments on yield, maturity and quality of Flame Seedless grapes (Vitis venifera L.). J Hort Sci. 88: 35-40.

Leao De Souza, P C, and Silva da, E E G. 2004. Effects of Hydrogen Cyanamid on Bud Breaking of the Grapevine'Italia'in the São Francisco River Valley. In III International Symposium on Tropical and Subtropical Fruits 864 (pp. 157-162).

Lombard, P.J., Viljoen J A, Wolf E E H and Calitz F J. 2004. The effect of ethephon application on the berry colour of Flame Seedless and Bonheur table grapes. S Afr J Enol Vitic. 25: 1-12.

Mehta, P.K., and Chundawat B S. 1979. Effect of ethephon on quality and ripening of Beauty Seedless grape. Vitis. 18: 117-21.

Muhtaseb, J., \& Ghnaim H. 2008. Budbreak, fruit quality and maturity of 'Superior' seedless' grapes as affected by Dormex $®$ under Jordan Valley conditions. Fruits. 63: 171-78.

Pandey, S.N., 1989. Hastening bud burst and ripenings in Pusa Seedless grapes (Vitis vinifera L.) with Dormex. Indian J Hort. 46: 348-52.

Panwar, K.S., Sharma S and Sehrawat K S. 1994. Effect of plant growth regulators on uneven ripening of Beauty Seedless grapes (Vitis vinifera L.) colour development and preharvest berry drop. Int J Trop Agric. 12: 15862.

Peppi, M.C., Fidelibus M W and Dokoozlian N. 2006. Abscisic acid application timing and concentration affect firmness, pigentation and colour of 'Flame Seedless' grapes. Hort Sci. 41: 1440-45.

Quiroga, A.M., Berli F J, Moreno D, Cavagnaro J B and Bottini R. 2009. Abscisic acid sprays significantly increase yield per plant in vineyard grown wine grape (Vitis vinifera L.) cv. Cabernet Sauvignon through increased berry set with no negative effects on anthocyanin content and total polyphenol index of both juice and wine. $\mathrm{J} \mathrm{Pl}$ Growth Regulation. 28: 28-35.

Setha, S., 2012. Roles of abscisic acid in fruit ripening. Walailak J Sci Tech. 9: 297-308.

Singla, R.K., Chharia A S and Kumar S. 1992. Effect of ethephon on ripening and quality of grape cultivars Early Muscat and Gold. Haryana J Hort Sci. 21(1-2): 39-42.

Spayed, S.E., Tarara J M, Mee D L and Ferguson J S. 2002. Sepration of sunlight and temperature effects on the composition of Vitis vinifera cv. "Merlot berries". Am J Enol Vitic? 53: 171-82.

Van der Merwe, G.G., Geldenhuys P D and Botes W S. 1991. Guide lines for the production of table grapes cultivars for export. Unifruco Ltd., Capetown, South Africa pp. 14-16 (Flame Seedless). 46-48 (Boneheur).

Yamane, T., and Shibayama K. 2006. Effect of trunk girdling and crop load level on fruit quality and root elongation in 'Aki Queen' grapes. J Japanese Soc Hort Sci. 75: 439-44.

\section{How to cite this article:}

Ashok Kumar Mahawer, N.K. Arora and Gill, M.I.S. 2017. Effect of Pre-Harvest Application of Hydrogen Cyanamide and Abscisic Acid (ABA) on Time of Ripening and Fruit Quality of Flame Seedless Grape (Vitis vinifera L.). Int.J.Curr.Microbiol.App.Sci. 6(10): 727-734. doi: https://doi.org/10.20546/ijcmas.2017.610.089 